\title{
Introduction: In 1959 the Electron Microscope Produces Astounding Images of the Alveolar Secretory Cell
}

\author{
Margaret C. Neville
}

Published online: 4 August 2009

(C) Springer Science + Business Media, LLC 2009

In 1945 Keith Porter and his colleagues at the Rockefeller Institute published the first electron micrographs of cultured cells, one of which showed 'details of a darker lace-like reticulum which in places appears to be made up of chains of "vesicles" [1]. He went on to name this structure the endoplasmic reticulum. By 1954 cytological techniques had advanced to the stage where tissue sections could be faithfully preserved for EM observation, and a clear view of the rough endoplasmic reticulum of a parotid secretory cell was obtained [2]. Elsewhere anatomy departments were establishing electron microscope facilities, and it was not long before images of the mammary gland began to appear, most notably from Dorothy Pitelka and her colleagues at the Department of Anatomy at Berkeley who demonstrated viral particles in the mammary glands of $\mathrm{C} 3 \mathrm{H}$ mice in 1958 [3], and from Professor Wolfgang Bargmann at the University of Kiel in Germany who, with A. Knoop, published what is often regarded as the definitive morphological study of the secreting mammary alveolar cell in 1959 [4]. We reproduce a shorter article by Bargmann and Welsch here [5], an article that deals with the formation of the casein micelle in the Golgi apparatus, the mechanism of secretion of the milk fat globule, and the presence of cytoplasmic feet at the basal surface with numerous coated vesicles in the cytoplasm just above the feet. The authors

M. C. Neville $(\square)$

UCDenver School of Medicine,

Aurora, CO, USA

e-mail: peggy.neville@ucdenver.edu suggest that these coated vesicles take up substances from the extracellular space, and indeed such vesicles have recently been found to transport both $\operatorname{IgA}$ and albumin to the lumen of the lactating mammary gland in mice $[6,7]$. Bargmann and Welsch also commented on a pronounced vesiculation on the surface of the myoepithelial cell; it is now clear that these flask-shaped surface vesicles represent caveoli $[6,8]$.

\section{References}

1. Porter KR, Claude A, Fullam EF. A study of tissue culture cells by electron microscopy. J Exp Med. 1945;81:233-244. + Plates.

2. Palade GE, Porter KR. Studies on the endoplasmic reticulum. I. Its identification in cells in situ. J Exp Med. 1954;100:641-56.

3. Pitelka DR, Bern HA, DeOme KB, Schooley CN, Wellings SR. Viruslike particles in hyperplastic alveolar nodules of the mammary gland of the $\mathrm{C} 3 \mathrm{H} / \mathrm{He} \mathrm{CRGL}$ mouse. $\mathrm{J}$ Natl Cancer Inst. 1958;20:541-53.

4. Bargmann W, Knoop A. Morphology of lactation; light \& electromicroscopic studies on the mammary glands of rats. Z Zellforsch Mikrosk Anat. 1959;49:344-88.

5. Bargmann W, Welsch U. On the ultrastructure of the mammary gland. In: Reynolds M, editor. Lactogenesis: the initiation of milk secretion at parturition. Philadelphia: University of Pennsylvania Press; 1969. p. 43-52.

6. Monks J, Neville MC. Albumin transcytosis across the epithelium of the lactating mouse mammary gland. J Physiol. 2004;560:267-280.

7. Monks J, Neville MC. Vesicular transport of soluble substances into mouse milk. Adv Exp Med Biol. 2001;501:257-63.

8. Hue-Beauvais C, Pechoux C, Bouguyon E, Chat S, Truchet S, Pauloin A, et al. Localisation of caveolin in mammary tissue depends on cell type. Cell Tissue Res. 2007;328:521-36. 